compounds (for a discussion of some recent work on these and on some other wound antiseptics see the Lancet, 90, Jan. 15, 1944), the sulphonamides and the quaternary ammonium compounds. 'Phemeride' ('Phemerol') is one of these and its action on bacteria is discussed by C. N. Fland (Lancet, 49, Jan. 8, 1944). It resembles the related substance 'Cetavlon' (CTAB) (seo J. M. Barnes, Lancet, 531, i, 1942, and R. Williams et al., Lancet, 522, i, 1943). Further work on the antibacterial action of organic detergents such as these should be interesting. The toxic action of 'Phemeride' and another detergent called 'Zephiran' on the tissues, and methods of studying their toxic action are discussed in an annotation in the Lancet (188, Feb. 5, 1944), together with work on the effect of antisepties on the metabolism of bacteria.

J. Gough, H. Berry and B. M. Still (Lancet, 176, Aug. 5, 1944) have tried 'Phenoxetol' on wounds, some of which were war wounds, and on burns, tuberculous cavities and cases of infected dermatitis. Most of the injuries treated were granulating areas associated with loss of skin and the need of skingrafting; and these authors are studying combinations of 'Phenoxetol' with penicillin, the sulphonamides and the flavines. They conclude that a daily application of $2 \cdot 2$ per cent solution of 'Phenoxetol' in water reduced the infection with $P s$. pyocyanea or eliminated it and resulted in clinical improvement. The addition of 5 per cent 'Phenoxetol' to the sulphonamide oream, which contains 'Cetavlon', devised by the Burns Unit of the Glasgow Royal Infirmary (see Med. Res. Council War. Memo., No. 10) was tried in vitro and the results were encouraging. But the toxicity of 'Phenoxetol' and its absorption need further study. It would seem that the blue pus of $P s$. pyocyanea, which was so common during the War of 1914-18 and did not then give rise to much anxiety, will shortly be controlled. It is proving, Gough and his colleagues state, an increasing nuisance in plastic surgery and skin-grafting. If future work discovers an opposite number to penicillin which will act with an equal efficiency on the Gram-negative organisms, then the labours of all those who are conducting the offensive against pathogenic micro-organisms will be well rewarded. Their problem will then be the reduction of the censiderable laboratory work which is necessary before a choice of antibacterial substance suitable for each case can be made.

Regulations governing the manufacture of penicillin have been issued by the Government. The manufacture and use of erude penicillium filtrate was discussed by J. M. Alston in the British Mediccl Journal (654, May 13, 1944). A further note in the same journal (314, Sept. 2, 1944) reviews two articles in American chemical engineering journals which describe the great effort which has been made to produce penicillin in quantity; it required the expenditure of millions of dollars at a time (1940 and 1941) when the sceptic might have doubted whether the effort was justified. More than twenty factories have been erected at a cost of gome 20 million dollars. The British Medical Journal (250, Aug. 19, 1944, and 317, Sept. 2, 1944) publishes notes on the use of penicillin for eivilian cases, and the Ministry of Health has issued two memoranda on the use of penicillin now being issued to medicel schools free of charge for the treatment of civilians. Next year there may be enough of it for all requirements. R. J. MeNeill Love (340, Sept. 9, 1944) records one of a number of air-raid casualties to whom penicillin was given as a prophylactic with very gratifying results. In a leading article the Lancet (348, Sept. 9, 1944) further discusses the manufacture and use of penicillin and gives further references. A. Dolphin (Brit. Med. J., 317, Sept. 2, 1944) has described the treatment of ten civilian cases at a meeting of the Fever Group of the Society of Medical Officers of Health, which was opened by Sir Alexander Fleming.

\section{LA SOCIÉTÉ FRANCAISE DE PHYSIQUE}

A $\mathrm{T}$ the meeting of the Physical Society on A November 9, the president, Prof. E. N. da C. Andrade, welcomed some French physicists, members of the sister society, la Société française de Physique. He said : "We have here Prof. P. Auger, Prof. G. A. Boutry and Dr. S. Rosenblum. Through the kind offices of M. Boutry, professeur au Conservatoire national des Arts et Métiers and a fellow of our Society, I have received a brief account of the history of the Société since the outbreak of war. In it the president, Prof. J. Cabannes, records the lamentable fate of many members whose names are known to, and honoured by, all of us." Prof. Andrade then read out the following names of those who had died, the assembly standing :

"G. Dechêne, J. Farineau, H. du Mesnil du Buisson and $J$. Rossignol fell on the field of honour in the early battles.

"F. Holweck, who made his name famous by his pump and by other ingenious instruments, by his work on soft $\mathrm{X}$-rays and by other notable researches, was murdered by the Gestapo; and J. Solomon, one of the most promising of the younger theoretical physicists, was shot by the German military authorities.

"Deaths that we have to deplore, some no doubt accelerated by the traditional brutalities of the Germans, are those of $H$. Buisson, H. Chipart, A. Dufour, A. Guillet, Victor Henri, J. Lemoine, Jean Perrin, Émile Picard and Pierre Weiss.

"Besides those who are known definitely to have lost their lives, there are others whose ultimate fate is unknown. H. Abraham, Eugene Bloch, G. Bruhat, L. Cartan, C. Sadron and J. Yvon have been deported to Germany, and we dare scarcely hope that they have received humane treatment there. Of Paul Langevin, who received in 1940 the highest honour the Royal Society has to give, the Copley Medal, we have no news, unless M. Boutry has something to tell us.

"Let me assure our French friends that although, as Mr. Eden said yesterday, 'People in Britain do not yet fully understand how complete, how merciless, how dastardly has been the devastation inflicted by the German armies in Allied lands as they withdraw', some of us here have some comprehension of German brutality. ..."

Prof. Andrade added that, in spite of obvious difficulties, "all through the troublous days of the German occupation, zealous and courageous French colleagues have kept alive the science of physics in France. In June 1941 appeared a new publication, the Cahiers de Physique; and the first number of another new publication, the Annales de Géphysique, is at this moment in the press. We congratulate our French brethren on the success of their strenuous efforts." 
Turning then to M. Boutry, Prof. Andrade said : "Au nom de la Physical Society je vous prie de bien vouloir saluer de notre part nos camarades de la Société française de Physique et de leur dire combien nous regrettons le lamentable sort de nos confrères, victimes du maudit système Nazi, ou plutôt allemand, combien nous espérons voir renaître dans toute sa gloire traditionelle et la France et la physique française. Nous avons remarqué avec la plus vive émotion comment, au milieu de tant de dangers et de difficultés, les physiciens français ont continué leurs travaux désinteressés. Tout ce que la Physical Society peut faire pour encourager et appuyer nos collègues, nos amis français, soyez assuré que ce sera fait. C'est pour nous un très grand bonheur de pouvoir désormais renouveler nos cordiales et traditionelles relations avec la Société française de Physique. Cher collègue, soyez le bienvenu."

In the course of his reply, Prof. Boutry said that Langevin is alive and well.

\section{OBITUARIES}

\section{Sir John Ledingham, C.M.G., F.R.S.}

Sur John LEDINGHAM, emeritus professor of bacteriology in the University of London and a former director of the Lister Institute of Preventive Medicine, died in London on October 4 after a brief illness. John Charles Grant Ledingham-'a son of the manse'-was born in 1875, his father, the Rev. John Ledingham, being the minister of Boyndie, Banffshire. He was educated at Boyndie Public School, Banff Academy, and the University of Aberdeen, where he achieved many successes including the Simpson and Arnott Prizes and the Anderson Scholarship. $\mathrm{He}_{\Theta}$ graduated with first-class honours in mathematics and physies, obtaining the B.Sc. degree with distinction. After a brilliant career in the Faculty of Medicine he obtained the M.B. degree with honours in 1902. Postgraduate study at the University of Leipzig and at the London Hospital followed, and in 1905 he joined the staff of the Lister Institute, being appointed assistant bacteriologist at Elstree and afterwards to the main institute at Chelsea. In 1909 he succeeded George Dean as chief bacteriologist, and on the retirement of Sir Charles Martin in 1930 he was appointed director of the Lister Institute.

During his tenure of the directorship of the Lister Institute, one of the most responsible posts in preventive medicine, Ledingham proved himself to be an able administrator and supervisor of research, while finding time to pursue his own researches on experimental studies of viruses and virus diseases. His investigations regarding the elementary bodies from vaccinial and smallpox material were a notable contribution to this subject. Later he studied the morphology and conditions of growth of the organisms of pleuro-pneumonia and allied conditions. Earlier in his career he carried out studies on the causation of purpura hæmorrhagica in man, on the mechanism of phagocytosis and on the epidemiology of the typhoid carrier state. He retired from the directorship of the Lister Institute in 1943. The University of London in 1920 had granted him the title of professor of bacteriology and, after his retirement, the title of emeritus professor was conferred on him in the present year.
During the War of 1914-18, Ledingham was ir. charge of the Bacteriological Department of King George Hospital and served afterwards in the Royal Army Medical Corps, with the rank of lieutenantcolonel, as member of the Medical Advisory Committee in the Mediterranean area and as consulting bacteriologist to the Forces in Mesopotamia. For these services he received the C.M.G. in 1918. He was elected to a fellowship of the Royal Society in 1921 and was knighted in $1937 . \mathrm{He}$ received the honorary degree of LL.D. from his own University of Aberdeen and also the honorary degree of doctor of science from the Universities of Dublin and Leeds. He was appointed a member of the Medical Researeh Council in 1934 and served on many expert scientific committees, being chairman of the Tropical Diseases Research Committee of the Medical Research Council and the Royal Society and a member of the War Wounds Committee in the present War. He was chairman of the British National Committee of the International Association of Microbiologists, president of the Second International Congress for Microbiology which was held in London in 1936 and was an honorary president of the Third (New York) Congress in 1939. He was largely instrumental in the formation of the National Collection of Type Cultures, sponsored by the Medical Research Council and domiciled at the Lister Institute, and was its director from its inception in 1920 until his appointment as director of the Lister Institute.

Some thirty papers were published under Ledingham's name or in collaboration with others during the period 1920-43; one of his outstanding achievements being a book written jointly with Sir Joseph Arkwright entitled "The Carrier Problem in Infectious Diseases", which was published in 1912. He was a noteworthy contributor to, and an associate editor of, the "System of Bacteriology" in nine volumes published by the Medical Research Council in 1930-31, as well as to the Council's "Treatise on Diphtheria". In 1924 he delivered the Harben Lectures in London and in 1934 the Herter Lectures at Johns Hopkins University, Baltimore.

Sir John Ledingham married in 1913 Barbara, daughter of David Fowler. They had two children, a son and a daughter, both of whom are following the discipline of medicine. His scientific attainments were of a high order; his life was dedicated to scientific research, and by precept and example he stimulated enthusiasm in others. His kindly and unassuming nature endeared him to colleagues and associates, and above all to those who were honoured by his personal friendship. R. ST. JоHN-BROoKs.

WE regret to announce the following deaths:

Prof. G. D. Birkhoff, Perkins professor of mathe. matics in Harvard University; on November 12, aged sixty.

Prof. D. M. Blair, regius professor of anatomy in the University of Glasgow, on November 10, aged forty-eight.

Prof. R. J. Rowlette, King's professor of materia medica and pharmacy in the School of Physic, Trinity College, Dublin, and preaident during 1940-43 of the Royal College of Physicians of Ireland, on October 13, aged seventy-one.

Prof. F. J. Wilson, Freeland professor of chemistry, Royal Technical College, Glasgow, on October 18, aged sixty-four. 